\title{
Biological Durability of Oil Heat Treated Alder Wood
}

\section{Biološka otpornost johovine termički modificirane u ulju}

\author{
Original scientific paper • Izvorni znanstveni rad \\ Received-prispjelo: 21. 12. 2012. \\ Accepted-prihvaćeno: 9. 4. 2014. \\ UDK: $630 * 844.53 ; 630 * 842 ; 674.031632 .15$ \\ doi:10.5552/drind.2014.1256
}

\begin{abstract}
The article presents preliminary results of the biological durability of oil heat treated (OHT) alder wood (Alnus glutinosa) against pure cultures of rot fungi (Postia placenta and Trametes versicolor) in lab conditions. The modification was performed by heating of specimens immersed in soya oil. There were four heating regimes of different duration (6 and 10 hours) at final temperature of 180 and $200{ }^{\circ} \mathrm{C}$. The increase in mass (MI) caused by modification and mass loss of wood caused by fungal decay (ML) were determined. In addition, the natural durability of alder wood was determined and compared to the natural durability of beech wood as the reference wood species.

After modification of alder wood at $200^{\circ} \mathrm{C}$, MI was lower than after treatment at $180^{\circ} \mathrm{C}$. MI was also lower after 10 hours of treatment than after 6 hours of treatment. The results showed significantly increased biological durability of modified alder wood against both tested fungi. The effect of OHT on increasing the biological durability of alder wood was higher against the fungus P. placenta. It seems that the fungus T. versicolor favours the remained oil after modification causing higher mass loss. The results showed that alder wood, thermally modified in soya oil by testing regimens, is not suitable for applications in use classes 3-5.
\end{abstract}

Key words: durability class, Postia placenta, soya oil, Trametes versicolor, use class

SAŽETAK - U radu su prezentirani preliminarni rezultati biološke otpornosti drva johe (Alnus glutinosa) termički modificiranoga u sojinu ulju protiv čistih kultura gljiva truležnica (Postia placenta i Trametes versicolor) u laboratorijskim uvjetima metodom mini blok prema CEN TS 15083-1. Modifikacija je izvedena zagrijavanjem uzoraka uronjenih u sojino ulje sobne temperature. Četiri načina termičke modifikacije razlikovala su se po trajanju držanja drva (6 i 10 sati) na konačnoj temperaturi (180 i $\left.200{ }^{\circ} \mathrm{C}\right)$. Usto je određena i prirodna otpornost johovine u usporedbi s prirodnom otpornosti bukovine kao referentne prirodno slabo otporne vrste drva. Mjereno je povećanje mase modifikacijom (DMM) i gubitak mase djelovanjem spomenutih gljiva (GMG). Nakon modifikacije pri višoj temperaturi DMM drva johe bio je manji nego nakon modifikacije pri nižoj temperaturi. Slično tome, dulji je tretman rezultirao nižim DMM-om nego kraći tretman. Rezultati su potvrdili povećanje biološke otpornosti modificirane johovine protiv obje testirane gljive truležnice. S povećanjem temperature modifikacije znatno se povećava biološka otpornost protiv obje gljive, dok produljenje vremena zagrijavanja ima blagi učinak povećanja biološke otpornosti. Utjecaj modifikacije na povećanje biološke otpornosti veći je protiv gljive smeđe truleži P. placenta. Utvrđeno je da je veći gubitkom mase modificiranih uzoraka djelovanjem gljive T. versicolor ( u usporedbi s gubitak mase djelovanjem gljive P. placenta) najvjerojatnije nastao zbog razaranja preostalog ulja

\footnotetext{
${ }^{1}$ Author is Head of Service of Final Wood Processing, Ministry of Agriculture, Directorate for Forestry, Hunting and Wood Industry, Zagreb, Croatia. ${ }^{2}$ Authors are assistant professor, professor, assistant professor, assistant and professor ${ }^{\dagger}$ at Faculty of Forestry, University of Zagreb, Zagreb, Croatia.

${ }^{1}$ Autor je voditelj Službe za finalnu preradu drva u Upravi za šumarstvo, lovstvo i drvnu industriju, Ministarstvo poljoprivrede, Zagreb, Hrvatska. ${ }^{2}$ Autori su, redom, docent, profesorica, docent, asistent i profesor ${ }^{\dagger}$ Šumarskog fakulteta Sveučilišta u Zagrebu, Zagreb, Hrvatska.
} 
u drvu nakon modifikacije. Dokaz tome je crvena boja mikroskopskih preparata modificiranih uzoraka (postojanje lignina) te lokalna plava obojenost u lumenima traheja (nedostatak lignina). U lumenima traheja ostalo je najviše ulja nakon modifikacije, pa se tu ujedno i najjače razvio micelij gljive bijele truleži T. versicolor, koji je, osim razgradnje ulja, djelomično uništio i lignin. Rezultati su pokazali da johovina termički modificirana u biljnom ulju, prema testiranim režimima, nije primjerena za upotrebu u razredima opasnosti 3 i višima.

Ključne riječi: Postia placenta, razredi opasnosti, razred trajnosti, sojino ulje, Trametes versicolor

\section{INTRODUCTION}

\section{UVOD}

Wood is a material that can be used for different purposes. However, it can be degraded by xylophagous microorganisms, xylophagous insects, UV rays, etc. (Hasan, 2010; Beyzar, 2012). It is flammable and hygroscopic, and its dimensions change depending on its moisture content. The above mentioned properties are undesirable and limit the application of wood in comparison to other new materials. There are many processes that can reduce/eliminate the undesired properties of wood. Hill (2006) mentioned some of the first scientists (Tiemann, 1915; Stamm and Hansen, 1937; Stamm et al., 1946; etc.) who have introduced various wood modification processes. The general goal of wood modification is to get wood with desirable properties during its service life, not toxic and not releasing any toxic substances (Hill, 2006). Among many modification processes, some chemical and thermal modifications have been the most investigated, but only some of them are commercialized.

Chemical modification implicates etherification or esterification between some chemical and $\mathrm{OH}$ groups of cellulose, hemicelluloses and lignin (Militz, 1993). The following parameters are important for successful chemical modification: temperature, type of chemical, processing time, type of catalyst and wood species (Hill, 2006; Hasan, 2010).

Thermal modification is a process where the wood cell wall polymers are destructed to the radicals that repolymerise with $\mathrm{OH}$ groups of wood cell wall compounds only by heating. Thermal modification is mostly conducted in operating cylinder at the temperature between 150 and $260{ }^{\circ} \mathrm{C}$ without the presence of oxygen (Leithoff and Peek, 1998; Rapp and Sailer, 2001a, 2001b; Rep and Pohleven, 2001; Yildiz et al., 2003; Hill, 2006; Beyzar, 2012). The type of heating medium, period of heating, final temperature and wood species are the most important parameters of thermal modification processes. By any such modification process, the dimensional stability and resistance of wood against rotfungi are improved (eg. Rapp and Sailer, 2001a, 2001b; Hill, 2006 mentioned Tiemann, 1915, Stamm and Hansen, 1937 and Stamm et al., 1946; Hasan et al., 2008; Beyzar, 2012), but some mechanical properties are decreased (Bengtsson et al., 2002; Ladner and Halmschlager, 2002; Patzelt et al., 2002; Bak and Nemeth, 2012). Resistance against fungi increases at increasing the degree of modification as well as at increasing the oil uptake (Rapp and Sailer, 2001b; Sidorova, 2009; Bazyar, 2012). Wood thermally modified in vegetable oils has greater durability against rot fungi than when modi- fied in air atmosphere (Rapp and Sailer, 2001a; Despot et al., 2008; Hasan et al., 2008; Hasan, 2010). Thermal modification of wood in air atmosphere at a final temperature ranging between 140 and $180{ }^{\circ} \mathrm{C}$ does not significantly increase biological durability compared to non-modified wood (Rapp and Sailer, 2001b; Hasan et al., 2006, 2007; Hasan, 2010; Despot et al., 2008). Feist and Sell (1987) reported that thermally modified wood was still sound without any sign of biodeterioration after 8 months of field testing. They explained that paucity of bluestain's and mould's mycelium on the surface of modified wood ensures reduced discoloration, and that durability against moulds and bluestain also increases with the increase of modification degree. They stated that the difference in discoloration becomes most significant between 8 and 14 months of field testing because the amount of simple carbohydrates decreases and chemical structure of parenchyma cells contents change during modification, so fungal enzymes become less effective (Feist and Sell, 1987).

Latest research reports that thermally modified wood is not resistant against staining fungi, and in some cases it becomes even more susceptible to staining fungi.

Sidorova (2009) modified spruce, pine heartwood, pine sapwood and aspen in rapeseed oil at 180 , 210 and $240{ }^{\circ} \mathrm{C}$ for $0.5,1.0$ and 1.5 hours. One set of specimens were taken away from the oil immediately after treatment and cooled in air atmosphere while the other set of specimens were cooled in the oil. Her results are similar to the results of Bazyar (2012). He also modified aspen wood in linseed oil at temperatures of 190, 205 and $220{ }^{\circ} \mathrm{C}$ for 4.5 and 6 hours. He reported that the WPG was about 83.9 to $86.2 \%$, and that the WPG was not significantly affected by time or temperature of modification. After the main heating stage, the oil was removed from the operating cylinder and specimens were vacuumed to remove surplus and remaining oil from the specimens. This is contrary to the results and procedure of Sidakova (2009).

Spear et al. (2006) reported the WPG of 89.9 and $87.4 \%$ in Corsican pine wood and below $20 \%$ in Norway spruce wood after oil heat treatment in linseed oil at 190 and $200{ }^{\circ} \mathrm{C}$, respectively, at decreased pressure. Bazyar (2012) cited similar WPG data of Sailer and Rapp (2001). The increase of mass of wood after oil heat treatment was about 42 to $51 \%$ for pine wood and 10 to $18 \%$ for spruce wood, depending on the immersion time of wood in oil during the cooling phase.

Bazyar (2012) explained high values of WPG in his study as a result of the small size of specimens. He cited Jones et al. (2005), who reported that longer sam- 
ples of sitka spruce have lower WPGs. Also, aspen is a hardwood with wide cells and it is permeable (Rowel 1984). He also explained that the high level of WPG could be related to anatomical changes of samples citing Hietala et al. (2002). Also Boonstra et al. (1998) reported that hardwood species such as beech and poplar are sensitive to the collapse of vessels and deformation of the libriform fibres near the vessels.

Oil heat treatment has been performed mainly on non-durable wood species such as spruce, fir and pine sapwood as well as on beech, alder and aspen (Bazyar, 2012; Sidorova, 2009; Hasan et al., 2008; Yildiz et al., 2003; Bengtsson et al., 2002; Patzelt et al., 2002; Rapp and Sailer, 2001a, 2001b; Feist and Sell, 1987). Alder wood is a fast growing hardwood species and it covers a wide area of Europe (Kajba and Gračan, 2003; Prpić and Milković, 2005). Technical properties of alder wood are poor and it is a non-durable wood species. The idea of the authors is to try to increase some properties of alder wood through modification and to increase its commercial importance. The article presents preliminary results of the mass increase (MI) and improved biological durability (in lab conditions) of oil heat treated alder wood against rot-fungi.

\section{MATERIALS AND METHODS} 2. MATERIJALI I METODE

Home-grown alder wood (Alnus glutinosa, L.) was used in the oil heat treatment and durability experiment. Beech wood (Fagus sylvatica L.) was used only untreated for comparison of the biological durability against the chosen test rot fungi, since it is reference species for natural durability rating due to its very low natural durability.

Lattices were sawn from the region close to the bark of an air-dried and afterwards kiln-dried (below $60{ }^{\circ} \mathrm{C}$ ) plank for each wood species. Specimens were cut to dimensions $15 \times 5 \times 30 \pm 0.2 \mathrm{~mm}(\mathrm{R} \times \mathrm{T} \times \mathrm{L})$. They were selected and marked successively according to CEN TS 15083-1 (2005) (Tab. 1).

Since Bak and Nemeth (2012) reported no significant influence of oil type on tested mechanical and physical properties, the cheapest oil on the market was used for this experiment. Soya oil was used as a heating medium, and the modification was performed in an open cylinder at ambient pressure.

\subsection{Modification procedure}

2.1. Postupak modifikacije

All specimens were oven dried at $103 \pm 2{ }^{\circ} \mathrm{C}$ for 48 hours to constant mass, weighed $\left(m_{1}\right)$, and then conditioned under the standard conditions $\left(20{ }^{\circ} \mathrm{C}\right.$ and $65 \%$ relative air humidity) to constant mass. Each group of specimens modified at the same regime (48 specimens) was immersed into 11 of fresh soya oil at room temperature. Then the oil was heated together with specimens. When the oil temperature of 180 and $200{ }^{\circ} \mathrm{C}$, respectively, was reached, the groups of specimens were boiled for further 6 and 10 hours, respectively. Immediately after modification, specimens were removed from the oil and cooled in air atmosphere over the silica gel and weighed again $\left(m_{2}\right)$.

\subsection{Determination of mass increase and natural durability}

2.2. Izračunavanje povećanja mase modifikacijom i određivanje biološke otpornosti

Increase of mass (MI) of modified specimens was calculated as a ratio of difference of oven-dried mass after modification $\left(m_{2}\right)$ and oven-dried mass before modification $\left(m_{1}\right)$ and $m_{1}(1)$.

$$
M I=\frac{m_{2}-m_{1}}{m_{1}} \cdot 100
$$

Diological durability of oil heat treated alder wood was determined according to CEN TS 15083-1 (2005). White rot fungus Trametes versicolor (L.: Fr.) Pilat. and brown rot fungus Postia placenta (Fr.) M.J. Larsen \& Lombard were chosen. "Potato dextrose agar (PDA)" by OXOID was used as a nutrient medium. Specimens were placed on the inert plastic network (1 $\mathrm{mm}$ thick) over the fungal mycelium in $90 \mathrm{~mm}$ Petri dishes and incubated for 9 weeks at $24 \pm 1{ }^{\circ} \mathrm{C}$ and $70 \pm$ $5 \%$ relative humidity.

Mass loss of specimens caused by fungal decay (ML) was calculated by dividing the difference of oven-dried mass of specimens after fungal decay $\left(m_{3}\right)$ and starting mass before decay $\left(m_{2}\right)$ with starting mass before decay $\left(m_{2}\right)(2)$.

Table 1 Distribution and number of specimens

Tablica 1. Raspored i broj uzoraka

\begin{tabular}{|c|c|c|}
\hline Fungus species / Vrsta gljive & Modification type / Postupak modifikacije & No. of specimens / Broj uzoraka \\
\hline \multirow{6}{*}{$\begin{array}{l}\text { Trametes versicolor (L.: Fr.) } \\
\text { Pilat. }\end{array}$} & Oil heat treated alder wood at $180^{\circ} \mathrm{C}, 6 \mathrm{~h}(\mathrm{OHT}-18 / 6)$ & 12 \\
\hline & Oil heat treated alder wood at $180^{\circ} \mathrm{C}, 10 \mathrm{~h}(\mathrm{OHT}-18 / 10)$ & 12 \\
\hline & Oil heat treated alder wood at $200^{\circ} \mathrm{C}, 6 \mathrm{~h}(\mathrm{OHT}-20 / 6)$ & 12 \\
\hline & Oil heat treated alder wood at $200^{\circ} \mathrm{C}, 10 \mathrm{~h}(\mathrm{OHT}-20 / 10)$ & 12 \\
\hline & Alder wood control (AC) & 24 \\
\hline & Beech wood control (BC) & 24 \\
\hline \multirow{6}{*}{$\begin{array}{l}\text { Postia placenta (Fr.) M.J. } \\
\text { Larsen \& Lombard }\end{array}$} & Oil heat treated alder wood at $180^{\circ} \mathrm{C}, 6 \mathrm{~h}(\mathrm{OHT}-18 / 6)$ & 12 \\
\hline & Oil heat treated alder wood at $180^{\circ} \mathrm{C}, 10 \mathrm{~h}(\mathrm{OHT}-18 / 10)$ & 12 \\
\hline & Oil heat treated alder wood at $200^{\circ} \mathrm{C}, 6 \mathrm{~h}(\mathrm{OHT}-20 / 6)$ & 12 \\
\hline & Oil heat treated alder wood at $200^{\circ} \mathrm{C}, 10 \mathrm{~h}(\mathrm{OHT}-20 / 10)$ & 12 \\
\hline & Alder wood control (AC) & 24 \\
\hline & Beech wood control (BC) & 24 \\
\hline
\end{tabular}




$$
M L=\frac{m_{2}-m_{3}}{m_{2}} \cdot 100
$$

This mass loss percentage ML $(\%)$ is the unit that shows the durability of specimens. ML will be smaller when the wood is more durable, and vice versa. The durability was ranked as proposed in CEN TS 15083-1 (2005).

\subsection{Examination of decay pattern using light microscopy}

2.3. Istraživanje mehanizma biološke razgradnje uz pomoć svjetlosnog mikroskopa

About $20 \mu \mathrm{m}$ thin sections were cut from alder wood specimens decayed by $T$. versicolor using Reichert-Shandon microtome. Sections were stained in safranin and astrablue solution. Cellulose in wood cell walls stained blue, while lignin stained red.

Stained slides were examined using Leitz Wetzlar light microscope, and photographs were taken at $100 \times$, $280 \times$ and $400 \times$ magnification.

\section{RESULTS AND DISCUSSION}

3. REZULTATI I RASPRAVA

\subsection{Mass increase (MI)}

3.1. Povećanje mase modifikacijom

It is known that wood specimens lose their mass during thermal modification due to the evaporation of extractives and of volatile compounds formed during thermolysis mainly of hemicelluloses and partly of lignin (Hill, 2006 quoted Shafizadeh and Chin, 1977 and Sudo et al., 1985; Rapp and Sailer, 2001b quoted Sandermann and Augustin, 1963, Kollmann and Fengel, 1965, Topf, 1971 and Tjeerdsma et al. 1998; Sidorova, 2009). Although mass increase during OHT process is the actual result of mass loss of wood and oil uptake in wood, many authors reported this mass increase as WPG.

In this experiment, it was impossible to remove the remained oil from the specimens with the available equipment, so the mass loss of specimens could not be determined. The oil remained in the specimens, so they gained mass. The results of mass increase (MI) indicate that by increasing either modification temperature or

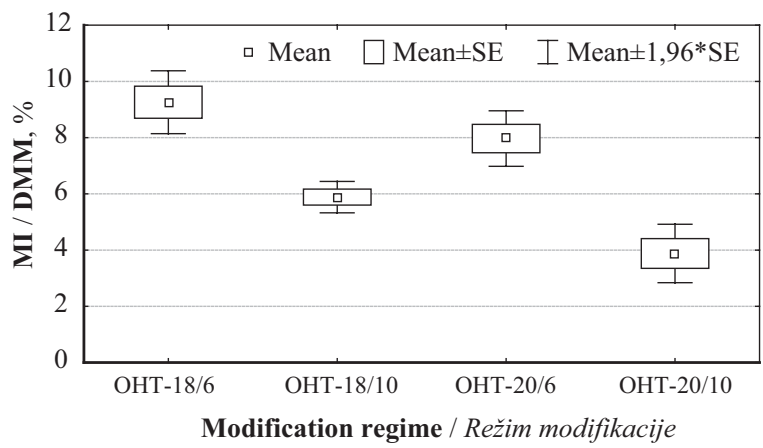

Figure 1 Mass increase of alder wood, MI after different modification regimes (OHT-18/6 $=180{ }^{\circ} \mathrm{C}, 6 \mathrm{~h}$; OHT-18/10 $=180{ }^{\circ} \mathrm{C}, 10 \mathrm{~h}$; OHT $-20 / 6=200^{\circ} \mathrm{C}, 6 \mathrm{~h}$; OHT-20/10 $=200$ ${ }^{\circ} \mathrm{C}, 10 \mathrm{~h}$ ).

Slika 1. Povećanje mase uzoraka johovine (DMM) nakon različitih režima modifikacije modification duration, MI of specimens significantly decreases (Fig. 1).

The obtained values of MI are similar to the results of Sidorova (2009). The only difference is that the mass increase of her specimens, which were cooled in the air, had the tendency to increase by increasing the time of modification at $180{ }^{\circ} \mathrm{C}$, while at higher temperatures of modification, mass increase tends to decrease by increasing the modification duration.

\subsection{Biological resistance against rot fungi \\ 3.2. Biološka otpornost protiv gljiva truležnica}

The results of this research confirmed significant increase of biological durability of modified alder wood compared to control specimens of both alder and beech wood. The biological durability of all modified alder wood specimens against both tested fungi was significantly higher than the controls. The effect of modification had greater impact on biological durability against $P$. placenta than against $T$. versicolor. By increasing the temperature, biological durability against both tested fungi increased. The only exception to this rule was found in ML caused by $T$. versicolor between OHT-18/10 and OHT-20/10 with no significant difference. Extended period of modification at both temperatures slightly affected, but not significantly, the increasing of biological durability (Fig 2 and 3). According to Rapp and Sailer (2001a, b), by increasing the mass loss of specimens during OHT, biological durability also increases.

Biological durability against both tested fungi of beech wood is slightly higher than that of alder wood. This can be explained by the difference in wood density between these two wood species (Fig 2 and 3).

Similar results of ML were obtained by Bayzar (2012) with aspen thermally modified in oil. Dirol and Guyonnet (1993) studied the effects of wood heat treatment at temperatures between 205 and $260{ }^{\circ} \mathrm{C}$ of three

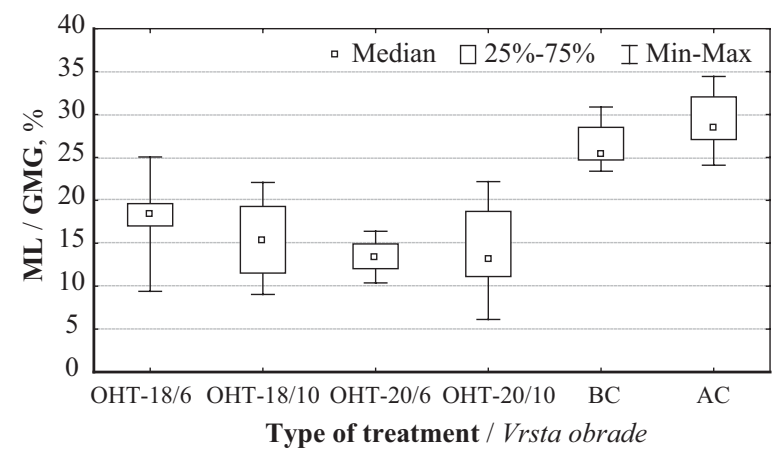

Figure 2 Mass loss of specimens caused by fungus Trametes versicolor (ML) of differently modified and non modified alder and beech wood (OHT-18/6 $=180^{\circ} \mathrm{C}, 6 \mathrm{~h}$; OHT- $18 / 10=180{ }^{\circ} \mathrm{C}, 10 \mathrm{~h}$; OHT- $20 / 6=200{ }^{\circ} \mathrm{C}, 6 \mathrm{~h}$; OHT-20/10 $=200^{\circ} \mathrm{C}, 10 \mathrm{~h}, \mathrm{AC}$-alder wood controls, BC-beech wood controls; $\mathrm{n}=24$ control specimens, $\mathrm{n}=12$ for OHT specimens).

Slika 2. Gubitak mase uzoraka djelovanjem gljive $T$. versicolor $(\mathrm{GMG})$ različito modificiranih uzoraka johovine $\mathrm{i}$ bukovine i nemodificiranih uzoraka 


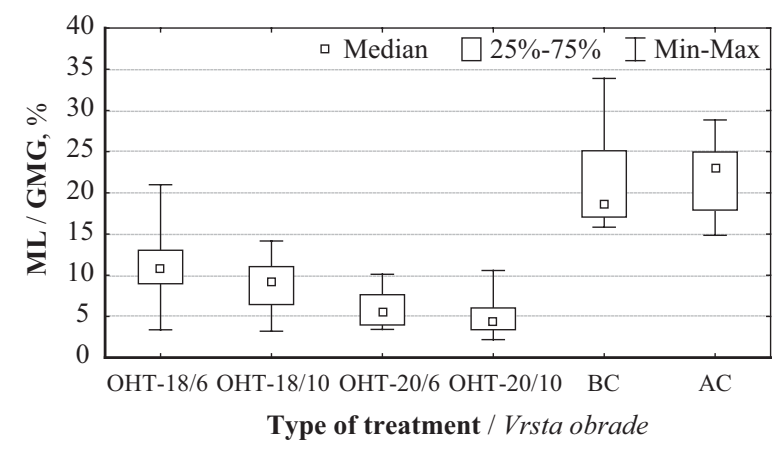

Figure 3 Mass loss of specimens caused by fungus Postia placenta (ML) of differently modified and non modified alder and beech wood (OHT- $18 / 6=180{ }^{\circ} \mathrm{C}, 6 \mathrm{~h}$; OHT-18/10 $=180{ }^{\circ} \mathrm{C}, 10 \mathrm{~h}$; OHT $-20 / 6=200{ }^{\circ} \mathrm{C}, 6 \mathrm{~h}$; OHT-20/10 $=200$ ${ }^{\circ} \mathrm{C}, 10 \mathrm{~h}, \mathrm{AC}$-alder wood controls, BC-beech wood controls; $\mathrm{n}=24$ for control specimens, $\mathrm{n}=12$ for OHT specimens).

Slika 3. Gubitak mase uzoraka djelovanjem gljive $P$. placenta $(\mathrm{GMG})$ različito modificiranih uzoraka johovine i bukovine i nemodificiranih uzoraka

non-durable wood species including poplar wood on resistance to several rot fungi including T. versicolor and Coniophora puteana. They reported mass loss of less than $1 \%$ for all modifications compared to mass loss of controls of $40 \%$. Rapp and Sailer (2001a, b) reported that spruce and pine sapwood oil heat treated at 190 to $220{ }^{\circ} \mathrm{C}$ have improved resistance to the fungus $C$. puteana. They reported the increase of mass loss from 48 and $40 \%$ to about 11 and $5.5 \%$ in pine sapwood and spruce, respectively. Welzbacher and Rapp (2002) showed that oil heat treatment of spruce and pine sapwood can improve durability against $T$. versiclor and $C$. puteana. Leithoff and Peek (2001) reported the temperatures above $170{ }^{\circ} \mathrm{C}$ to be effective for increasing biological resistance of two bamboo species.

The modification temperature of $180^{\circ} \mathrm{C}$, used in this research, does not significantly increase the durability class against white-rot fungus T. versicolor, while the modification at $200^{\circ} \mathrm{C}$ increases the durability from class 4 to class 3 . On the other hand, the temperature of $180^{\circ} \mathrm{C}$ increases the durability against brown-rot fungus $P$. placenta from class 4 to durability class 2-3, while the modification temperature of $200^{\circ} \mathrm{C}$ resulted in an increase of durability of OHT alder wood against brown-rot fungus $P$. placenta from class 4 do class 1-2.

Taking into account mass losses of both tested fungi, only the treatment at $200{ }^{\circ} \mathrm{C}$ can improve durability class of alder wood from class 4 to durability class 3 and hence broaden the application of alder wood.

\subsection{Decay pattern}

\subsection{Mehanizam biološke razgradnje}

Figure 4 shows the slides of non-decayed specimen that was oil heat treated at $200{ }^{\circ} \mathrm{C}$ for 10 hours. A lot of red colour and thickness of the wood cell double walls of the whole OHT slides prove completely non degraded wood (Fig. 4a and 4b).

Although OHT specimens of alder wood decayed by $T$. versicolor had greater ML compared to specimens decayed by $P$. placenta, the overall degree of wood degradation was very similar. Light microscopy examination shows that wood cell walls of OHT specimens decayed by $T$. versicolor were not as severely degraded as control specimens. The majority of blue colour of control slides proves the lack of lignin (great lignin degradation; Fig. 5a, 5b), while OHT slides are mainly red (proof of presence of lignin) with very local blue coloured regions (proof of lack of lignin; Fig. 5c, $5 \mathrm{~d}$ ). These very limited regions of blue colour are mainly in the vessels lumens. As the mycelium of the fungus T. versicolor was the most developed in the vessels lumens in OHT specimens, where the majority of oil remained (Olsson et al., 2001; Hill, 2006; Bazyar, 2012), it can be concluded that the fungus favours the presence of oil in wood (Fig. 5c, 5d, 6). This leads to the conclusion that the tested fungus $T$. versicolor mainly utilised the oil remained in vessels lumens causing grater ML, and also partially degraded lignin in the inner layer of the cell walls (blue colour; Fig. 5d). Another proof of poor and local lignin degradation in OHT specimens is the red colour of the whole OHT slides, which proves the presence of lignin, although $T$.
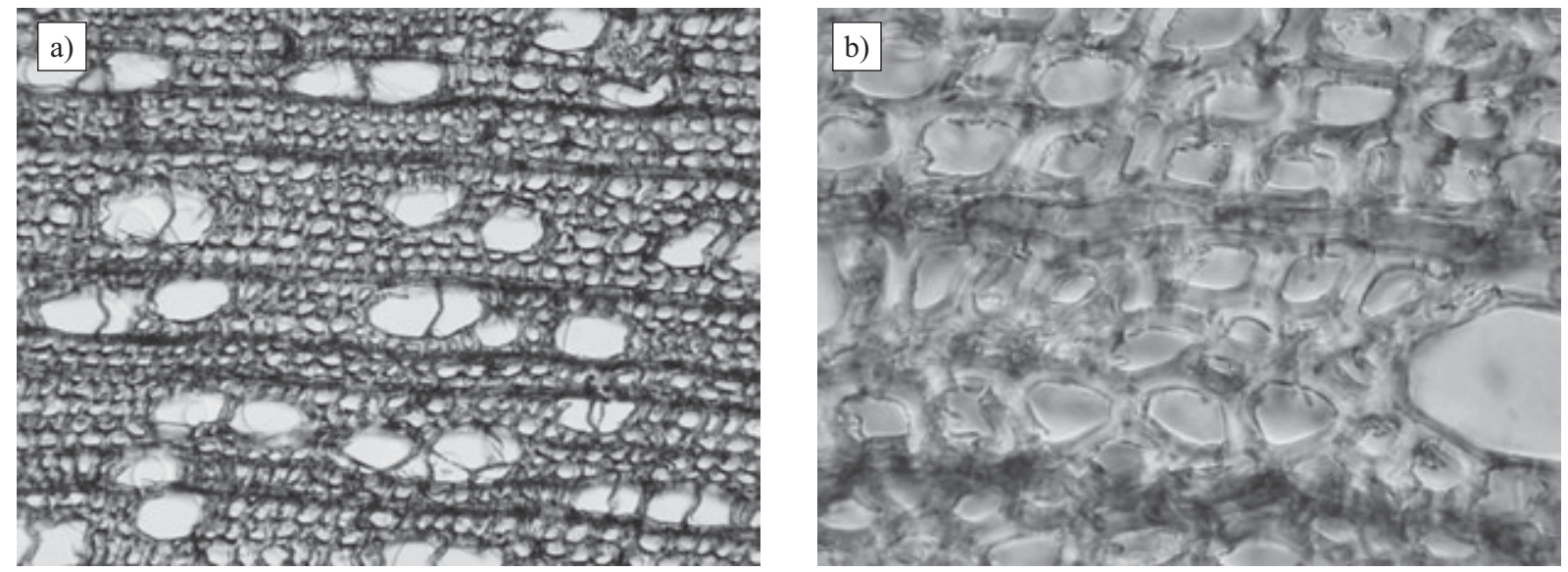

Figure 4 Cross section of non-decayed alder wood: a) OHT at $200^{\circ} \mathrm{C}$ for $10 \mathrm{~h}, 100 \times$; b) OHT at $200^{\circ} \mathrm{C}$ for $10 \mathrm{~h}, 400 \times$

Slika 4. Poprečni presjek nerazorenoga modificiranog uzorka johovine: a) OHT pri $200{ }^{\circ} \mathrm{C}$ za $10 \mathrm{~h}$, povećanje 100 puta;

b) OHT pri $200^{\circ} \mathrm{C}$ za $10 \mathrm{~h}$, povećanje 400 puta 

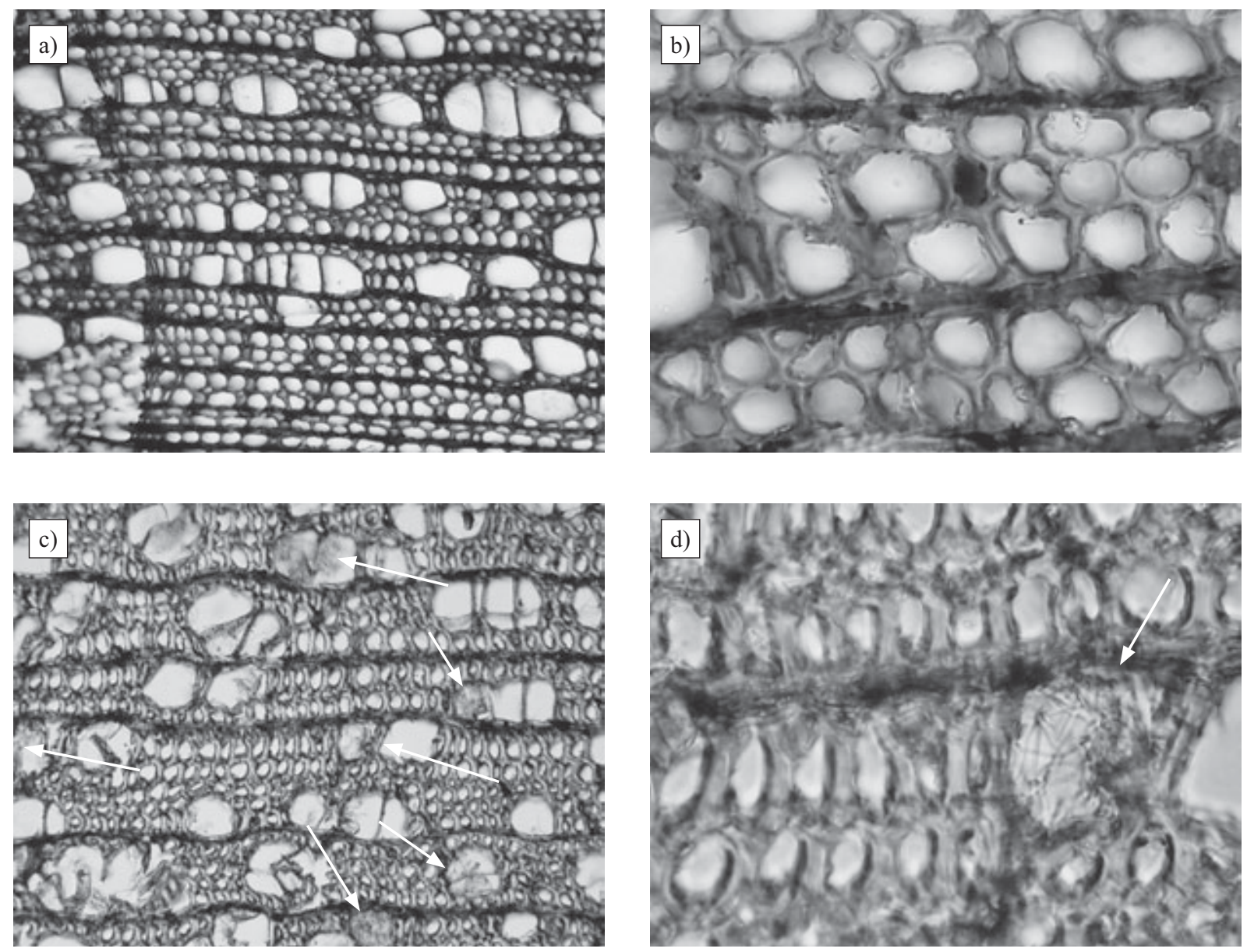

Figure 5 Cross section of alder wood decayed by white-rot fungus Trametes versicolor: a) control, 100×; b) control, 400×; c) OHT at $200^{\circ} \mathrm{C}$ for $10 \mathrm{~h}, 100 \times$; d) $\mathrm{OHT}$ at $200^{\circ} \mathrm{C}$ for $10 \mathrm{~h}, 400 \times$.

Slika 5. Poprečni presjek uzorka johovine razorenoga gljivom bijele truleži T. versicolor: a) kontrolni uzorak, povećanje 100 puta; b) kontrolni uzorak, povećanje 400 puta; c) OHT pri $200^{\circ} \mathrm{C}$ za $10 \mathrm{~h}$, povećanje 100 puta; d) OHT pri $200{ }^{\circ} \mathrm{C}$ za $10 \mathrm{~h}$, povećanje 400 puta

versicolor is white-rot fungus and predominantly degrades lignin (Fig. 5c and 6a). Comparing the thickness of wood cell double-walls of modified non-decayed specimen (Fig. 4b), of control decayed specimen (Fig. $5 \mathrm{~b}$ ) and of modified decayed specimen (Fig. 5d), it is visible that the thickness of cell double-walls of modified non-decayed specimen and modified decayed specimen are very similar. At the same time, the thickness of cell double-walls of control decayed specimen is visibly thinner and lumens are larger.
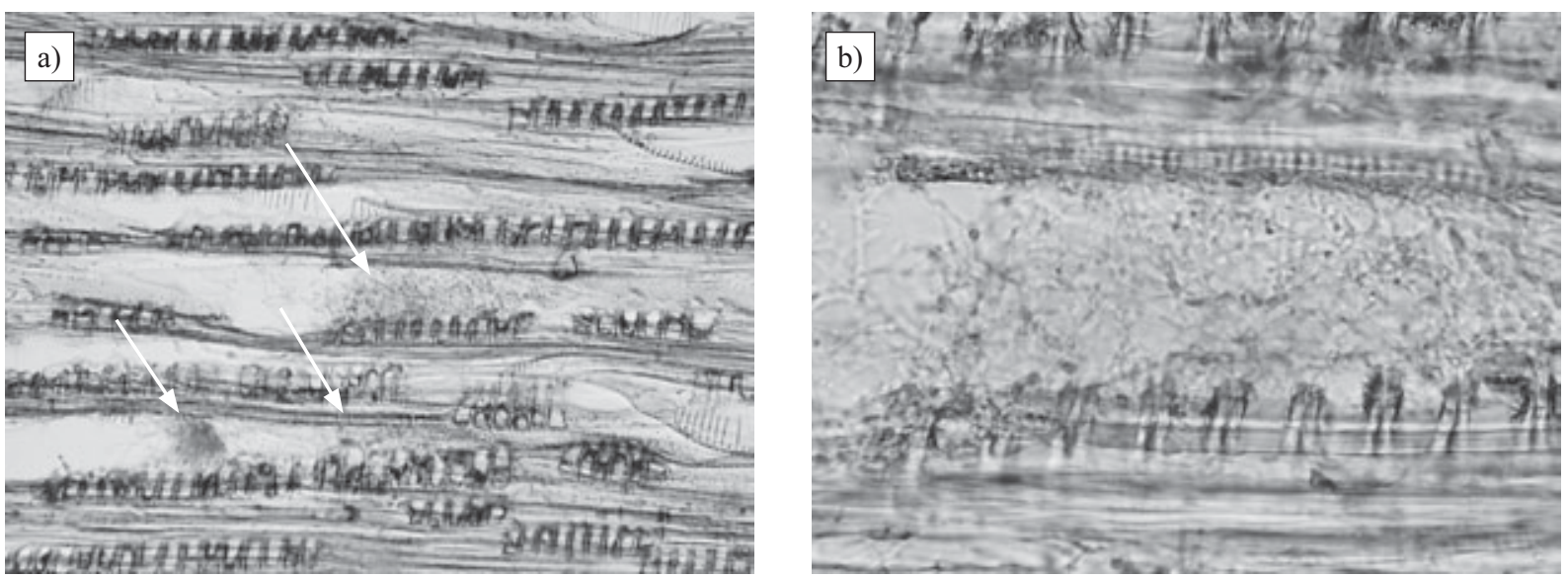

Figure 6 Tangential section of alder wood oil heat treated at $200{ }^{\circ} \mathrm{C}$ for $10 \mathrm{~h}$ decayed by white-rot fungus Trametes versicolor: a) magnification $100 \times$; b) magnification $400 \times$.

Slika 6. Tangentni presjek uzorka johovine modificiranog na $200{ }^{\circ} \mathrm{C} 10$ sati i razorenoga gljivom bijele truleži T. versicolor: a) povećanje 100 puta; b) povećanje 400 puta 
... Lacić, Hasan, Trajković, Šefc, Šafran, Despot: Biological Durability of Oil Heat Treated...

\section{CONCLUSION}

\section{ZAKLJUČAK}

The increase in mass of modified specimens decreased by increasing the duration of oil heat treatment modification at both tested temperatures. The results indicated that the increase of temperature as well as the increase of modification duration had a positive effect on biological durability of alder wood against tested fungi. The tested modification regimes were not adequate for the application of modified alder wood in use classes 3 to 5 .

Light microscopy showed that the mycelium of the fungus $T$. versicolor was the most developed in the vessels lumens of modified specimens. Greater mass loss of modified alder wood, decayed by this fungus, can be explained by the fungal utilisation of the oil remained in vessels lumens.

Oil heat treatment is a simple and environmentally friendly method by which biological durability against wood rot fungi can be relatively easily improved. However, it is very important to put in mind that such modification can produce significant decrease in mechanical properties. Further research will show the actual effect of OHT on mechanical properties of alder wood.

\section{REFERENCES}

\section{LITERATURA}

1. Bak, M.; Nemeth, R., 2012: Modification of wood by oil heat treatment. Proceedings: The Impact of Urbanization, Industrial and Agricultural Technologies on the Natural Environment. Nemenyi, M., Heil, B. (Ed.). International Scientific Conference on Sustainable Development \& Ecological Footprint. March 26-27 2012, Sopron, Hungary. pp. 1-5. (C) Nyugat-magyarországi Egyetem, Sopron, Hungary.

2. Bengtsson, C.; Jermer, J.; Brem, F., 2002: Bending strength of heat-treated spruce and pine timber. International Research Group on Wood Protection. Doc. No.: IRG/WP 02-40242.

3. Bazyar, B., 2012: Aspen decay \& oil heat treatment. BioResources. 7(1): 696-705.

4. Boonstra, M. J.; Tjeerdsma, B. F.; Groeneveld, H. A. C., 1998: Thermal modification of non-durable wood species. 1. The PLATO technology: thermal modification of wood. International Research Group on Wood Preservation, Doc. No. IRG/WP 98-40123.

5. Despot, R.; Hasan, M.; Jug, M.; Šefc, B., 2008: Biological durability of wood modified by citric acid. Drvna industrija 59(2): 55-59.

6. European Committee for Standardisation 2005: CEN TS 15083-1: Durability of wood and wood-based products - Determination of the natural durability of solid wood against wood-destroying fungi, test methods - Part 1: Basidiomycetes.

7. Feist, W. C.; Sell, J., 1987: Weathering Behaviour of Dimensionally Stabilized Wood Treated by Heating under Pressure of Nitrogen Gas. Wood and Fiber Science 19(2): 183-195.

8. Hasan, M.; Despot, R.; Trajković, J.; Šefc, B., 2006: Role of modification processes at increasing biological durability of wood. International conference European Union - Challenges and perspectives for the wood-pro- cessing industry. Proceedings. Zagreb, October 13th, pp. 153-158.

9. Hasan, M.; Despot, R.; Jug, M., 2007: Modifikacija drva limunskom kiselinom u cilju poboljšanja biološke otpornosti. International conference: Nove tehnologije i materijali u industrijama baziranim na sektoru šumarstva. Proceedings, Zagreb, 19. October 2008, pp. 85-89 [in Croatian language].

10. Hasan, M.; Despot, R.; Šafran, B.; Lacić, R.; Peršinović, M., 2008: Oil heat treatment of alder wood for increasing biological durability of wood. Wood is good-properties, technology, valorisation, application. Grbac, I.; JiroušRajković, V. (Ed.). Zagreb: University of Zagreb, Faculty of Forestry, 2008. pp. 121-125.

11. Hasan, M., 2010: The influence of different modification procedures onto biological durability of modified wood. Dissertation, University of Zagreb, Faculty of Forestry. 08. 06. 2010 Zagreb. pp. 259 [in Croatian language].

12. Hill, C. A. S., 2006: Wood Modification: Chemical, Thermal and other processes. Wiley, UK, pp. 260. http://dx. doi.org/10.1002/0470021748.

13. Kajba, D.; Gračan, J., 2003: Technical guidelines for genetic conservation and use for Black Alder (Alnus glutinosa). EUROGENT, International Plant Genetic Resources Institute, Rome, Italy. $6 \mathrm{pp}$.

14. Ladner, C.; Halmschlager, E., 2002: Dauerhaftigkeit von modifiziertem Holz gegenüber holzzerstörenden Pilzen, Chapter in the book: Modifiziertes Holz: Eigenschaften und Märkte, Lignovisionen Band 3, September 2002, pp. 191-219 [in German language].

15. Leithoff, H.; Peek, R. D., 1998: Hitzebehandlung - eine Alternative zum chemischen Holzschutz. Tagungsband zur 21. Holzschutz-Tagung der DGfH in Rosenheim. pp. 97-108. [in German language].

16. Leithoff, H.; Peek, R. D., 2001: Heat treatment of bamboo. International Research Group on Wood Protection. Doc. No. IRG/WP 01-40216. pp. 1-11.

17. Militz, H., 1993: Treatment of timber with water soluble dimethylol resins to improve their dimensional stability and durability. Wood Science and Technology 27(4): 347-355. http://dx.doi.org/10.1007/BF00192221.

18. Olsson, T.; Megnis, M.; Varna, J.; Lindberg, H., 2001: Measurement of the uptake of linseed oil in pine by the use of X-ray micro densitometry technique. Journal of Wood Science. 47(4): 275-281 http://dx.doi.org/10.1007/ BF00766713.

19. Patzelt, M.; Stigl, R.; Teischinger, A., 2002: Thermische Modifikation von Holz und deren Einfluß auf ausgewählte Holzeigenschaften. Chapter in the book: Modifiziertes Holz: Eigenschaften und Märkte. Lignovisionen Band 3, September 2002, pp. 101-147 [in German language].

20. Prpić, B.; Milković, I., 2005: Rasprostranjenost poplavnih suma u prošlosti i danas. Chapter in the Book: Poplavne šume u Hrvatskoj, Vukelić, J. (Ed.), Akademija šumarskih znanosti, Zagreb, pp. 23-39. [in Croatian language].

21. Rapp, A. O.; Sailer, M., 2001a: Oil-heat-treatment of wood - process and properties. Drvna industrija 52(2): 63-70.

22. Rapp, A. O.; Sailer, M., 2001b: Oil heat treat treatment of wood in Germany - State of the art. Review on heat treatments of wood. COST Action E22, Environmental optimisation of wood protection. Proceedings of the special seminar held in Antibes, France. $9^{\text {th }}$ February 2001, Forestry and Forestry Products, France. pp. 45-62.

23. Rep, G.; Pohleven, F., 2001: Wood modification - a promising method for wood preservation. International Conference: Wood in construction industry: Tradition and future. Zagreb, Croatia, $25^{\text {th }}$ April 2001, pp. 27-38. 
24. Spear, M. J.; Hill, C. A. S.; Curling, S. F.; Jones, D.; Hale, M. D., 2006: Assessment of the envelope effect of three hot oil treatments: Resistance to decay by Coniophora puteana and Postia placenta. International Research Group on Wood Protection. Doc. No.: IRG/WP 06-40344.

25. Sidorova, K., 2009: Oil Heat Teatment of Wood. 2009:001. ISSN: 1653-0187. ISRN: LTU-PB-EX-09/001--SE pp. 6. Web article: http://epubl.ltu.se/16530187/2009/001/LTU-PB-EX-09001-SE.pdf downloaded on 4th April 2014.

26. Welzbacher, C. R.; Rapp, A. O., 2002: Comparison of thermally treated wood originating from four industrial scale processes - durability. International Research Group on Wood Protection. Doc. No.: IRG/WP 02-40229.
27. Yildiz, S.; Yildiz, Ü.; Çolakođlu, G.; Derya, E.; Temýz Ali, G., 2003: The Effects of heat Treatment on the specific Gravity of Beech and Spruce Wood. International Research Group on Wood Protection. Doc. No.: IRG/WP 03-40254.

\section{Corresponding address:}

Assistant Professor MARIN HASAN, Ph.D.

Faculty of Forestry Zagreb

Svetošimunska cesta 25, HR-10002 Zagreb, CROATIA

E-mail: mhasan@sumfak.hr 